\title{
Effects of the HIF-1 $\alpha$ and NF-кB loop on epithelial-mesenchymal transition and chemoresistance induced by hypoxia in pancreatic cancer cells
}

\author{
ZHUO-XIN CHENG $^{1,3^{*}}$, DA-WEI WANG ${ }^{2,3^{*}}$, TAO LIU $^{1}$, WEI-XIN LIU ${ }^{1}$, WEI-BIN XIA ${ }^{1}$, JIAN XU ${ }^{1}$, \\ YING-HAI ZHANG ${ }^{1}$, YI-KUN QU ${ }^{1}$, LIN-QI GUO ${ }^{1}$, LONG DING ${ }^{1}$, JIE HOU ${ }^{1}$ and ZHAO-HUA ZHONG ${ }^{3}$ \\ ${ }^{1}$ Department of General Surgery, The First Affiliated Hospital of Jiamusi University, Jiamusi 154002; \\ ${ }^{2}$ Department of General Surgery, The First Affiliated Hospital of Harbin Medical University, Harbin 150001; \\ ${ }^{3}$ Department of Microbiology, Harbin Medical University, Nangang, Harbin 150081, P.R. China
}

Received November 22, 2013; Accepted January 17, 2014

DOI: 10.3892/or.2014.3022

\begin{abstract}
Hypoxia is a microenvironmental factor which plays a critical role in tumor development and chemoresistance. Epithelial-to-mesenchymal transition (EMT) induced by hypoxia is one of the critical causes of treatment failure and chemoresistance in different types of human cancers. Stabilization of the hypoxia-inducible factor- $1 \alpha$ (HIF-1 $\alpha)$ transcription complex, caused by intratumoral hypoxia, promotes tumor progression and chemoresistance. Previous evidence suggests that hypoxia can also activate nuclear factor- $\kappa B$ (NF-kB), a known mediator of EMT, which is accompanied by reduced expression of epithelial marker E-cadherin and enhanced expression of the mesenchymal markers Vimentin and $\mathrm{N}$-cadherin as well as overexpression of various transcription factors of EMT, such as Snail and Twist. Based on this evidence, the present study aimed to investigate whether downregulation of the p65 subunit of NF-kB or HIF-1 $\alpha$ by small interfering RNA (siRNA) may reverse the EMT phenotype and inhibit the proliferation and induce the apoptosis of pancreatic cancer cell lines (PANC-1, BxPC3) under hypoxic conditions in vitro and enhance the efficacy of gemcitabine in the treatment of pancreatic cancer. These results provide molecular evidence showing that the activation of the HIF-1 $\alpha$ and NF- $\mathrm{KB}$ loop is mechanistically linked with the chemoresistance phenotype (EMT phenotype) of pancreatic cancer cells under hypoxic conditions, suggesting that the inactivation of HIF-1 $\alpha$ and NF- $\mathrm{BB}$ signaling by novel strategies may be a
\end{abstract}

Correspondence to: Professor Zhao-Hua Zhong, Department of Microbiology, Harbin Medical University, 157 Biaojian Road, Nangang, Harbin 150081, P.R. China

E-mail: chengzhuoxin@126.com

"Contributed equally

Key words: epithelial-to-mesenchymal transition, hypoxia, pancreatic cancer, chemoresistance, HIF- $1 \alpha$, NF- $\kappa$ B loop potential targeted therapeutic approach for overcoming EMT and chemoresistance induced by hypoxia.

\section{Introduction}

Pancreatic cancer, which is one of the most aggressive and lethal cancers worldwide, is highly resistant to chemotherapy (1). Even systemic therapy with gemcitabine, a current first-line treatment for advanced pancreatic cancer, offers only modest benefit due to pre-existing or acquired chemoresistance $(2,3)$. Furthermore, clinical studies indicate that only $12 \%$ of patients with advanced pancreatic cancer exhibit a response to gemcitabine (4). The poor response rate suggests that pancreatic cancer either rapidly develops or has intrinsic gemcitabine chemoresistance. The mechanisms by which chemoresistance arises in pancreatic cancer are unknown; thus a better understanding of how resistance arises and what molecular alterations cause or correlate with resistance is likely to lead to novel therapeutic strategies for pancreatic cancer.

Hypoxia is an environmental stimulus that plays a key role in the development and progression of cancer. Tumoral hypoxia or expression of hypoxia-inducible factor-1 (HIF-1) has been linked to an aggressive phenotype which correlates with a poor response to chemotherapy and a worse overall survival of cancer patients $(5,6)$. HIF-1 is a heterodimeric protein consisting of a constitutively expressed subunit, HIF-1 $\beta$, and an oxygen-sensitive inducible subunit, HIF-1 $\alpha$. Under normoxia, the HIF-1 $\alpha$ protein is hydroxylated by a family of oxygen-dependent prolyl hydroxylases (PHD1-3); this targets it for polyubiquitination by a protein complex containing von Hippel-Lindau protein (pVHL) and then degradation (7). Under hypoxic conditions, prolyl hydroxylases are inactivated and HIF-1 $\alpha$ degradation is blocked; this allows HIF-1 $\alpha$ to accumulate and associate with HIF-1 $\beta$ to form a functional transcription complex that triggers the transcription of a host of hypoxia-inducible genes (7).

Epithelial-to-mesenchymal transition (EMT) is the process by which adherent epithelial cells convert to motile mesenchymal cells and is essential in embryonic development. EMT is now known to also occur in a variety of diseases including 
the progression of cancer (8). In a previous study, evidence was provided suggesting that moderate hypoxic conditions can trigger, acting as an independent factor, an EMT program leading different human cancer cells to significantly increased invasiveness (9). Detailed examinations of the multiple facets of the EMT program have revealed its involvement in more than just invasion and metastasis; previous studies show that the phenotype of EMT is associated with chemoresistance in a diverse array of solid tumors (10-17).

Nuclear factor- $\kappa \mathrm{B}(\mathrm{NF}-\kappa \mathrm{B})$ is a ubiquitous transcription factor regulated by numerous stimuli including hypoxia, cytokines and chemotherapeutic drugs, and has recently emerged as a target for cancer. $\mathrm{NF}-\kappa \mathrm{B}$ is constitutively activated in most $(>70 \%)$ human pancreatic cancer cells and in primary tumor specimens, but not in normal pancreatic tissues or nontumorigenic cell lines (18-20). Previous studies have shown that hypoxia activates NF- $\kappa \mathrm{B}(21,22)$, and induces the resistance of pancreatic cancer cells to gemcitabine (23), whereas $\mathrm{NF}-\kappa \mathrm{B}$ can also regulate HIF-1 $(24,25)$. Some studies have also reported that activation of $\mathrm{NF}-\kappa \mathrm{B}$ is closely involved in the progression of EMT (26-29). Recently, we reported that dihydroartemisinin or small interfering RNA (siRNA) inactivates $\mathrm{NF}-\kappa \mathrm{B}$ and potentiates the antitumor effect of gemcitabine on pancreatic cancer both in vitro and in vivo $(30,31)$. Compared with HIF-1 $\alpha$, the regulation of $\mathrm{NF}-\kappa \mathrm{B}$ and EMT during hypoxia has been less studied, and although the phenomenon was previously observed, the molecular mechanisms involved remain unclear. Thus, we sought to determine the role of the HIF- $1 \alpha$ and NF- $\kappa$ B loop in the hypoxic microenvironment in pancreatic cancer. Therefore, the present study was designed to investigate whether downregulation of the p65 subunit of $\mathrm{NF}-\kappa \mathrm{B}$ or HIF- $1 \alpha$ by siRNA may reverse the EMT phenotype and inhibit the proliferation and induce the apoptosis of pancreatic cancer cells (PANC-1, BxPC3) under hypoxic conditions and enhance the efficacy of gemcitabine to treat pancreatic cancer.

\section{Materials and methods}

Cell lines and reagents. The human pancreatic cancer cell lines BxPC-3 and PANC-1 were obtained from the American Type Culture Collection (Rockville, MD, USA). Both cell lines were routinely cultured at $37^{\circ} \mathrm{C}$ in RPMI-1640 medium supplemented with $10 \%$ fetal calf serum, penicillin $(100 \mathrm{U} / \mathrm{ml})$ and streptomycin $(100 \mu \mathrm{g} / \mathrm{ml})$ in an incubator with $95 \%$ air and $5 \% \mathrm{CO}_{2}$. Hypoxic control cells were incubated under the same conditions but in a hypoxic incubator (Precision Scientific, Winchester, VA, USA) with $1 \% \mathrm{O}_{2}, 5 \% \mathrm{CO}_{2}$ and $94 \% \mathrm{~N}_{2}$. The antibodies against NF- $\mathrm{B}(\mathrm{p} 65)$, SNAI1(H-130), TWIST(H-81) and $\beta$-actin were purchased from Santa Cruz Biotechnology, Inc. (Santa Cruz, CA, USA). The HIF-1 $\alpha$ Ab was purchased from Abcam Inc. (Cambridge, MA, USA). The Vimentin, E-cadherin and $\mathrm{N}$-cadherin Abs were purchased from ZSGB-BIO Inc. (Beijing, China). Annexin V-FITC and propidium iodide (PI) were purchased from Sigma Inc. (Beijing, China). Gemcitabine was purchased from Lily France (Fegersheim, France).

Preparation of siRNAs and transfection. To knock down the HIF-1 $\alpha$ and NF- $\kappa$ B p65 subunit, synthesized siRNA duplexes were obtained from Invitrogen. A double-stranded siRNA (p65 siRNA) (sense, 5'-GCCCUA UCCCUU UACGUC A-3' and antisense 5'-UGACGU AAAGGG AUAGGG C-3') with two introduced thymidine residues at the $3^{\prime}$ end, which encode amino acid residues 347 and 353 of the NF- $\mathrm{NB}$ p65 subunit was designed to target the NF- $\mathrm{B}$ p 65 subunit as described previously (31). Based on a previous report (32), the sequences of two oligonucleotides targeting $\mathrm{HIF}-1 \alpha$ were as follows; sense, 5'-GGGUAA AGAACA AAACAC A-3' and antisense 5'-UGUGUU UUGUUC UUUACC C-3'. BxPC-3 and PANC-1 cells were grown to $50 \%$ confluency in 6- or 96-well plates, and transfected with the siRNAs in serum-free medium without antibiotic supplements using Lipofectamine ${ }^{\mathrm{TM}} 2000$ (Invitrogen). Cells were allowed to stabilize for $48 \mathrm{~h}$ before being used in the experiments. Silencing of protein expression was confirmed by western blot analysis.

Assessment of cellular morphological changes and determination of cell viability. Cellular morphology was evaluated using phase-contrast microscopy, and images were captured with a computer-imaging system (Olympus Q-Color 3RTV camera). Cell viability was determined by the Cell Counting Kit-8 assay (Dojin Laboratory, Kumamoto, Japan) and crystal violet assay.

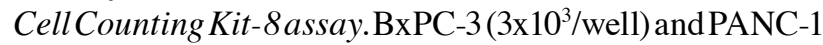
$\left(4 \times 10^{3} /\right.$ well $)$ cells were split into a $96-$ well plate and incubated overnight in a humidified $\mathrm{CO}_{2}$ incubator $(95 \%$ air and $5 \%$ $\mathrm{CO}_{2}$ ) to allow the cells to adhere and assume a healthy condition, and were then exposed to gradient doses of gemcitabine (0-200 $\mu \mathrm{mol} / \mathrm{l})$ for $48 \mathrm{~h}$ under hypoxic and normoxic conditions. The cells were then incubated with WST-8 solution at $37^{\circ} \mathrm{C}$ for $1 \mathrm{~h}$, and the absorbance at $450 \mathrm{~nm}$ was measured on a microplate reader (MPR-A4i; Tosoh Corporation, Tokyo, Japan). The cells cultured in RPMI-1640 medium served as the control. The cell viability index was calculated according to the formula: Experimental OD value/control OD value x $100 \%$. All experiments were carried out in triplicate and repeated thrice.

Crystal violet assay. The cells $\left(5 \times 10^{4} /\right.$ well) were seeded into 6-well plates and cultured overnight. Then the medium was replaced with complete culture medium containing gemcitabine $(10 \mu \mathrm{mol} / 1$ for PANC-1 and $500 \mathrm{nmol} / 1$ for BxPC-3 cells) for an additional $48 \mathrm{~h}$ under hypoxic and normoxic conditions. Cells were then washed twice with pre-warmed PBS, and then the cells remaining were stained for $2 \mathrm{~h}$ with a crystal violet solution ( $0.5 \%$ crystal violet, $20 \%$ methanol). After removal of the crystal violet solution, the plates were washed three times by immersion in a beaker filled with tap water. Plates were left to dry at $37^{\circ} \mathrm{C}$, and then the images were captured by camera.

Detection of cell apoptosis. After the designated treatment, BxPC-3 and PANC-1 cells were washed, harvested and counted. Cells $\left(1 \times 10^{6}\right)$ were resuspended in $100 \mu \mathrm{l}$ binding buffer, before $5 \mu \mathrm{l}$ of Annexin $\mathrm{V}$ and $5 \mu \mathrm{l}$ of PI were added, and incubated for $15 \mathrm{~min}$ at room temperature in the dark, according to the manufacturer's instructions (Biosea, China). The apoptosis rate (\%) was measured in a cytometer (Epics Altra II; Beckman Coulter, USA). Cells were viewed under a laser scanning confocal microscope (LSM-510; 
Carl Zeiss Jena GmbH, Jena, Germany) to visualize those that had undergone apoptosis. The experiment was repeated thrice.

Electrophoretic mobility shift assay (EMSA). EMSA was performed by incubating $10 \mu \mathrm{g}$ of nuclear protein, prepared according to a method described previously (30), with Gel Shift Binding buffer and $1 \mu \mathrm{g}$ of poly(deoxyinosinic-deoxycytidylic acid) at $4^{\circ} \mathrm{C}$ for $30 \mathrm{~min}$, and then mixed with biotin-labeled oligonucleotide bio-NF- $\kappa$ B probe (5'-AGTTGA GGGGAC TTTCCC AGGC-3') at room temperature for $20 \mathrm{~min}$, according to the manufacturer's instructions (Viagene, Beijing, China). The resulting DNA-protein complex was separated from the free oligonucleotide on a $4 \%$ polyacrylamide gel containing $0.25 \mathrm{X}$ TBE (Tris/borate/EDTA) buffer. The dried gels were visualized with a Cool Imager imaging system (IMGR002), and radioactive bands were quantified using Scion Image software.

Western blotting. The methodology was described previously (30). Briefly, 5x105 cells were sonicated in RIPA buffer and homogenized. Debris was removed by centrifugation at $12,000 \mathrm{x} \mathrm{g}$ for $10 \mathrm{~min}$ at $4^{\circ} \mathrm{C}$. The samples containing $50 \mu \mathrm{g}$ protein were electrophoresed on polyacrylamide SDS gels, and transferred to polyvinylidene difluoride (PVDF) membranes. The membranes were blocked with 3\% BSA, incubated with primary antibodies, and subsequently with alkaline phosphatase-conjugated secondary antibody. They were developed with 5-bromo-4-chloro-3-indolyl phosphate/nitro blue tetrazolium (Tiangen Biotech Co. Ltd., Beijing, China). Blots were also stained with anti- $\beta$-actin $\mathrm{Ab}$ as the internal control for the amounts of target proteins.

Statistical analysis. The results are expressed as mean values \pm standard deviation, and a Student's t-test was used to evaluate statistical significance. A value of $<0.05(\mathrm{P}<0.05)$ was used to indicate statistical significance.

\section{Results}

Morphological and cell biological changes characteristic of EMT under hypoxic conditions. In preliminary experiments, 65-70\% subconfluent pancreatic cancer cells (PANC-1, BxPC3) were exposed to hypoxic conditions $\left(1 \% \mathrm{O}_{2}, 5 \% \mathrm{CO}_{2}\right.$ and $94 \% \mathrm{~N}_{2}$ ) up to $48 \mathrm{~h}$. As reported previously (9), PANC-1 cells exposed to hypoxia up to $48 \mathrm{~h}$ underwent typical morphological and cellular changes of EMT; PANC-1 cells started to loose cell contacts, scattered from cell clusters and acquired a spindle-shaped and fibroblast-like phenotype. In the BxPC3 cell lines, however, morphological and cellular changes did not significantly differ (Fig. 1A).

To further confirm whether pancreatic cancer cells underwent EMT when exposed to hypoxia, we also determined the expression of markers of epithelial and mesenchymal phenotypes by western blotting. Induction of EMT was previously demonstrated in both cell lines after hypoxia, as shown by a shift in expression of epithelial markers (E-cadherin) to mesenchymal markers (Vimentin and $\mathrm{N}$-cadherin) and various transcription factors of EMT, such as Snail and Twist, were overexpressed $(33,34)$. We found that pancreatic cancer cells (PANC-1, BxPC3) after exposure to hypoxia for $48 \mathrm{~h}$ had
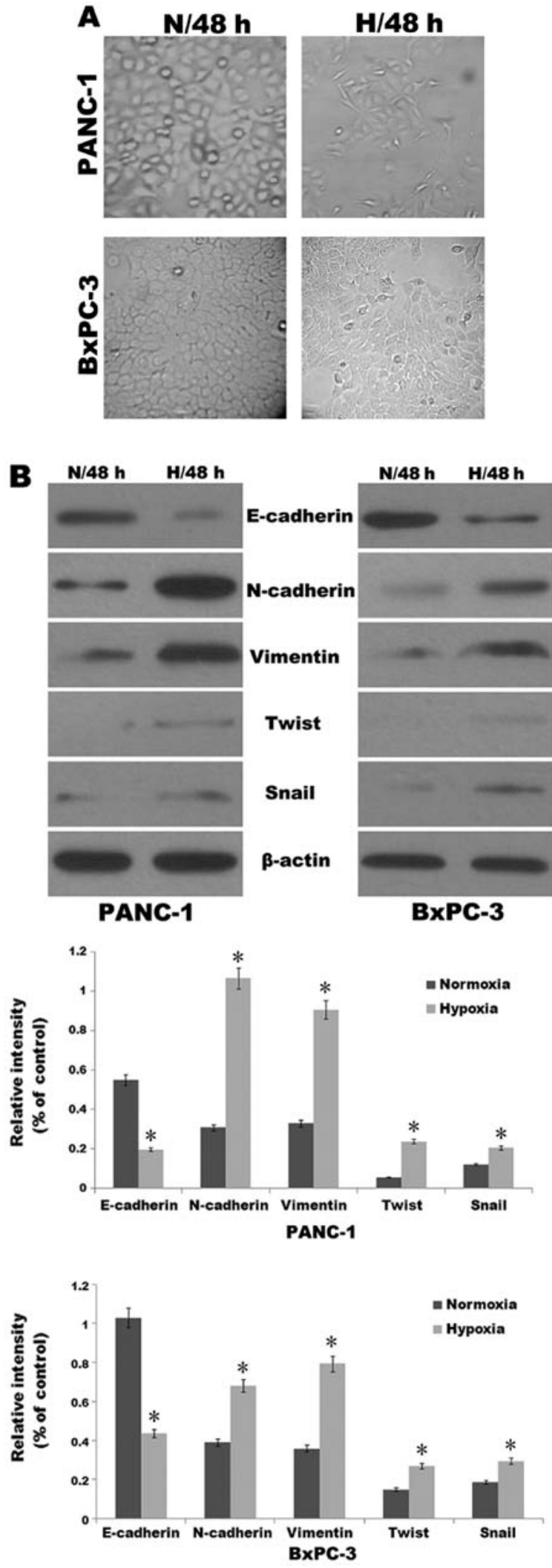

Figure 1. Hypoxia induces an EMT-like fibroblastoid phenotype in pancreatic cancer cells. (A) Phase contrast analysis (original magnification, $\mathrm{x} 100$ ) of morphological changes detected in human pancreatic cancer cell lines under normoxic $\left(\mathrm{N}, 21 \% \mathrm{O}_{2}\right)$ or hypoxic $\left(\mathrm{H}, 1 \% \mathrm{O}_{2}\right)$ conditions. Representative images were captured after a 48-h incubation. (B) Western blot analysis of the expression of E-cadherin, Vimentin, $\mathrm{N}$-cadherin, Snail and Twist from respective cell homogenate, with $\beta$-actin used as a protein loading control. Bottom panels: relative intensity of data presented in the top panels, compared with the protein loading control. ${ }^{*} \mathrm{P}<0.05$, significant difference in the relative intensity when compared to a normoxic condition $\left(\mathrm{N}, 21 \% \mathrm{O}_{2}\right)$. EMT, epithelial-to-mesenchymal transition. 


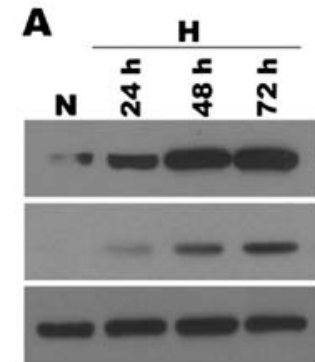

PANC-1

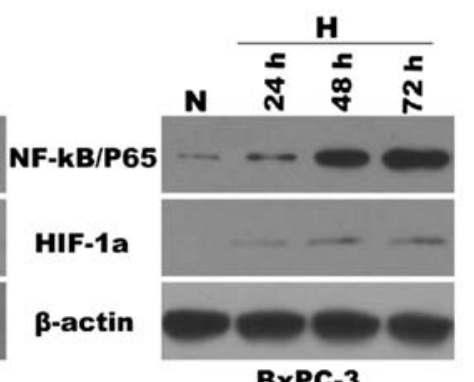

BxPC-3
C
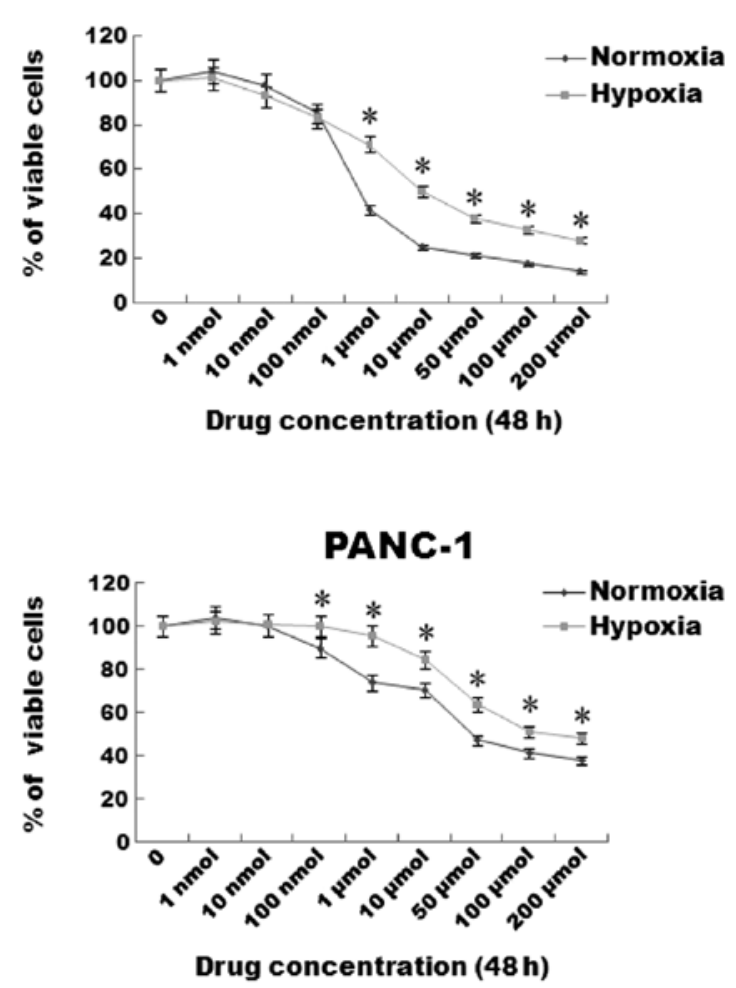

B
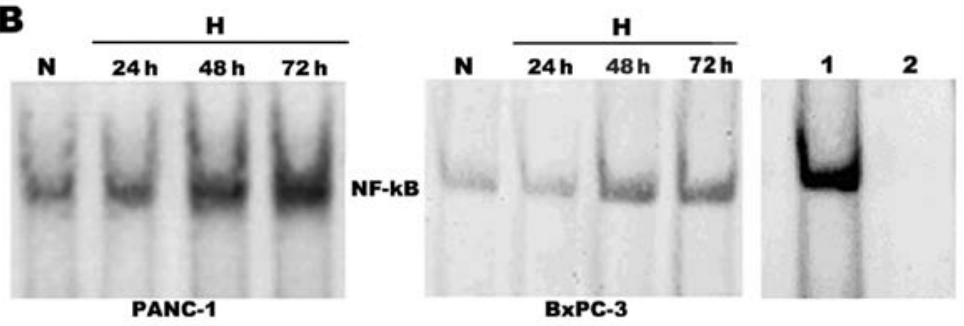

BXPC-3

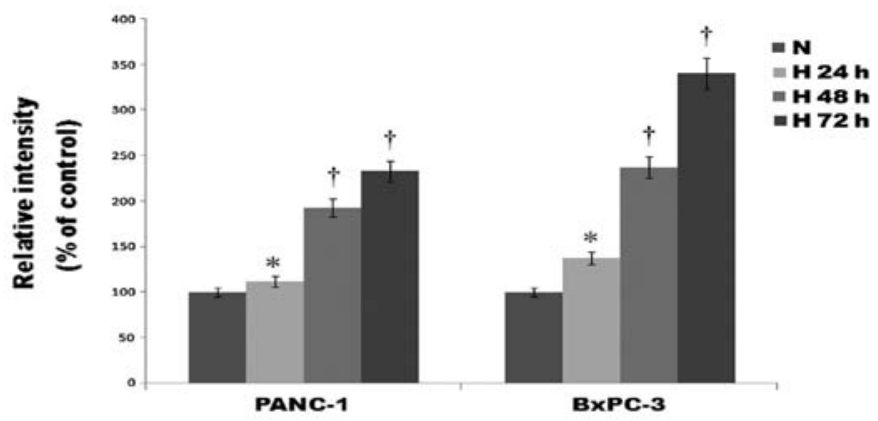

D
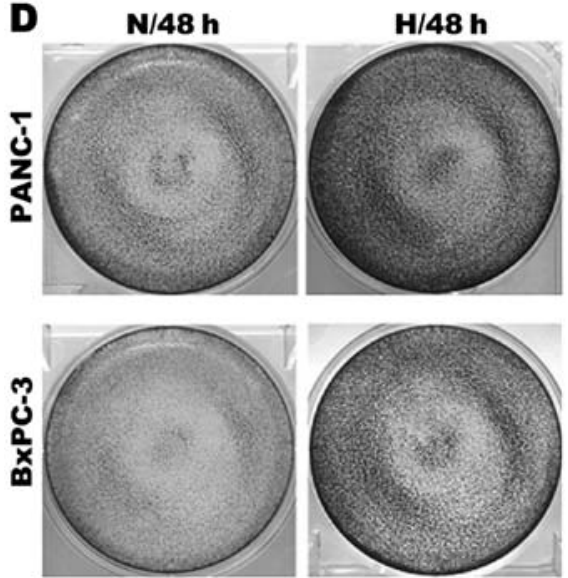

Figure 2. Hypoxia induces HIF-1 $\alpha$ and NF- $\mathrm{kB}$ overrexpression and decreases the susceptibility to gemcitabine of pancreatic cancer cells. PANC-1 and BxPC-3 cells were cultured under normoxic $\left(\mathrm{N}, 21 \% \mathrm{O}_{2}\right)$ or hypoxic conditions $\left(\mathrm{H}, 1 \% \mathrm{O}_{2}\right)$ for various time periods $(24,48$ and $72 \mathrm{~h})$. After each indicated incubation period, the cells were collected. Nuclear extracts and total protein extracts were prepared. (A) HIF-1 $\alpha$ and NF-kB(p65) were analyzed by western blot analysis from respective cell homogenates, with $\beta$-actin used as the protein loading control. (B) Electrophoretic mobility shift assay (EMSA) for NF- $\mathrm{kB}$ DNA binding activity of the respective nuclear extracts. Competitive assay confirmed the specificity of NF-kB binding to the DNA. Lane 1 , control; lane 2 , excess unlabeled ('cold') NF- $\kappa B$ oligonucleotide. Bottom panel: densitometric quantification of the data presented in the top panel. "P<0.05 and 'P<0.01, compared with normoxia. (C) PANC-1 and BxPC-3 cells were divided into two groups (normoxia/ $\mathrm{N}$ and hypoxia/H) and then exposed to gradient doses of gemcitabine $(0-200 \mu \mathrm{mol} / \mathrm{l})$ for $48 \mathrm{~h}$. Cell Counting Kit- 8 assay was used to assess the cell viability rate. ${ }^{*} \mathrm{P}<0.05$, significantly higher cell viability rate when compared to normoxia $\left(\mathrm{N}, 21 \% \mathrm{O}_{2}\right)$. (D) The proliferation of cells was also measured by crystal violet assay. Images were selected as representative scenes from three independent experiments. HIF-1 $\alpha$, hypoxia-inducible factor- $1 \alpha$; NF- $\kappa B$, nuclear factor- $\kappa \mathrm{B}$.

reduced expression of E-cadherin and increased expression of Vimentin, N-cadherin, Snail and Twist when compared with cells under a normoxic condition (Fig. 1B).

Hypoxia induces $H I F-1 \alpha$ and $N F-\kappa B$ hyperexpression and decreases the susceptibility to gemcitabine of pancreatic cancer cells. Studies have previously shown that hypoxia results in activation of NF- $\mathrm{BB}(21,22)$ and EMT. Thus, we sought to determine whether the EMT observed in pancreatic cancer cells (PANC-1, BxPC3) was attributable to heightened NF- $\kappa B$ activity. First, to verify the expression of NF- $\mathrm{KB}$ and HIF-1 $\alpha$ during hypoxia, pancreatic cancer cells were incubated under hypoxic conditions for different periods of time
(24, 48 and $72 \mathrm{~h}$ ). After each indicated incubation period, the cells were collected, and total and nuclear proteins were extracted. HIF-1 $\alpha$ and NF- $\kappa$ B were analyzed by western blot analysis (Fig. 2A). The NF-kB DNA binding activity was also determined by EMSA (Fig. 2B). Expression levels of HIF-1 $\alpha$ and NF- $\kappa B$ proteins were increased $24 \mathrm{~h}$ after the initiation of hypoxic treatment and reached a maximum by $72 \mathrm{~h}$. NF- $\kappa$ B DNA binding activity was also increased $24 \mathrm{~h}$ after initiation of hypoxia and reached maximum activity by $72 \mathrm{~h}$. These data demonstrated that the expression levels of HIF-1 $\alpha$ and NF- $\kappa \mathrm{B}$ were increased under hypoxia when compared to these levels under normoxic conditions in a time-dependent manner. Moreover, some studies have previously shown that 


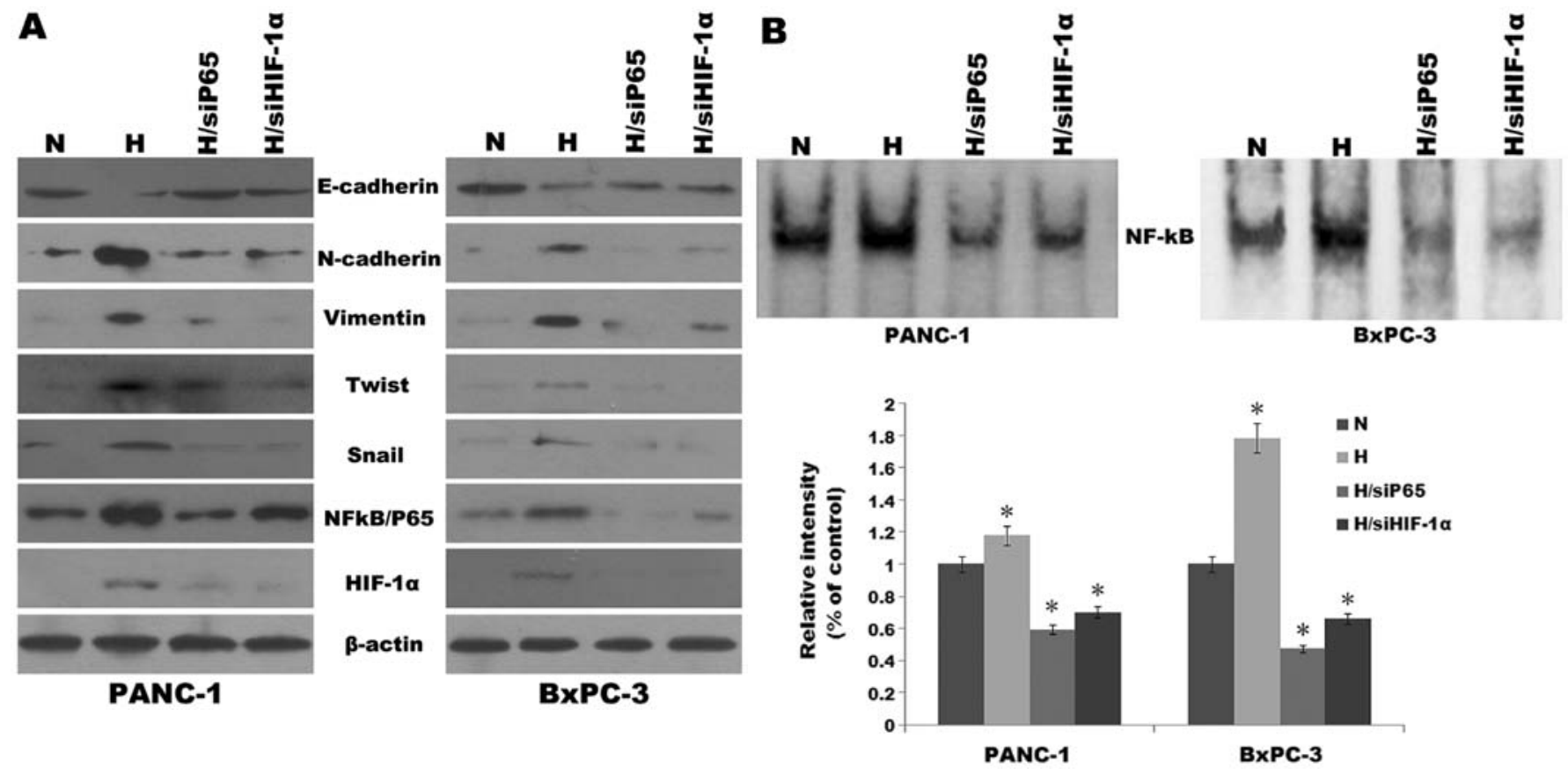

Figure 3. HIF-1 $\alpha$ siRNA (siHIF-1 $\alpha$ ) and NF- $\mathrm{kB}(\mathrm{p} 65)$ siRNA (siP65) reverse EMT in pancreatic cancer cells under hypoxic conditions and regulate each other. Cells were transfected with siHIF-1 $\alpha$ and siP65, and then incubated under hypoxic conditions (H) for $48 \mathrm{~h}$. (A) Western blot analysis of the expression

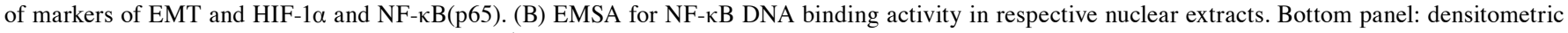
quantification of data presented in the top panel. " $\mathrm{P}<0.05$, compared with normoxia (N). HIF-1 $\alpha$, hypoxia-inducible factor- $1 \alpha$; NF- $\kappa \mathrm{B}$, nuclear factor- $\kappa \mathrm{B}$; siRNA, small interfering RNA; EMT, epithelial-to-mesenchymal transition; EMSA, electrophoretic mobility shift assay.

EMT is a key step of drug resistance in a number of different tumors (10-17). Thus, we sought to examine the effects of EMT induced by hypoxia on the response to gemcitabine by pancreatic cancer cells. Pancreatic cancer cells, PANC-1 and BxPC-3, were divided into two groups (N/normoxia and $\mathrm{H} /$ hypoxia) and exposed to gradient doses of gemcitabine (0-200 $\mu \mathrm{mol} / \mathrm{l})$ for $48 \mathrm{~h}$. Cell Counting Kit-8 assay was used to assess the cell viability rate. Data are shown in Fig. $2 \mathrm{C}$. When treated with concentrations of gemcitabine $>100 \mathrm{nmol} / \mathrm{l}$, hypoxia cells showed a significantly higher cell viability rate when compared with the normoxia cells $(\mathrm{P}<0.05)$ (Fig. 2C). These results were further confirmed by crystal violet assay (Fig. 2D). When treated with gemcitabine (10 $\mu \mathrm{mol} / \mathrm{l}$ for PANC-1 and $500 \mathrm{nmol} / \mathrm{l}$ for BxPC-3) for $48 \mathrm{~h}$, cells incubated under hypoxic conditions showed a significantly higher cell viability rate than that under a normoxic condition. Together, these findings validate the involvement of hypoxia in the activation of NF- $\mathrm{NB}$ and HIF-1 $\alpha$ stabilization and chemoresistance to gemcitabine in pancreatic cancer cells.

Effects of HIF-1 $\alpha$ and $N F-\kappa B$ on EMT under hypoxic conditions. To test the effects of HIF-1 $\alpha$ and NF- $\kappa \mathrm{B}$ on the expression of specific EMT markers under hypoxic conditions, we knocked down NF- $\mathrm{NB}$ using siRNA in pancreatic cancer cells (PANC-1, BxPC3). As shown in Fig. 3A, the cells manifested reduced E-cadherin expression and increased Vimentin, $\mathrm{N}$-cadherin, Snail and Twist expression under hypoxic conditions when compared with cells under normoxic conditions. Similar results were obtained when we silenced HIF-1 $\alpha$ using siRNA. It has been shown that downregulation of $\mathrm{NF}-\kappa \mathrm{B}$ or HIF- $1 \alpha$ is associated with EMT. Furthermore, cells that have undergone EMT tend to exhibit greater chemoresistance. The next question that remained to be addressed was whether HIF- $1 \alpha$ and NF- $\kappa$ B contributed to the formation of the resistance. We examined these properties in pancreatic cancer cells (PANC-1, BxPC3) with flow cytometry to confirm the role of HIF- $1 \alpha$ and $\mathrm{NF}-\kappa \mathrm{B}$ in cells that underwent EMT resisting the apoptosis induced by gemcitabine. To test this, BxPC-3 and PANC-1 cells were transfected with HIF-1 $\alpha$ siRNA and $N F-\kappa B(p 65)$ siRNA respectively, and the transfectants were treated with gemcitabine for $48 \mathrm{~h}$ under normoxic and hypoxic conditions. NF- $\kappa \mathrm{B}(\mathrm{p} 65)$ siRNA or HIF-1 $\alpha$ siRNA both abrogated the increase in NF- $\kappa \mathrm{B}$ DNA binding activity induced by hypoxia when compared to the activity under normoxia and reversed the resistance of pancreatic cancer cells to gemcitabine. Furthermore, we also performed western blotting and EMSA (Fig. 3B) to determine the correlation between the expression of HIF- $1 \alpha$ and NF- $\kappa \mathrm{B}$ under hypoxic conditions. As shown in Fig. 3A, NF- $\kappa \mathrm{B}(\mathrm{p} 65)$ siRNA had an effect on the expression of HIF-1 $\alpha$ when compared to the control under hypoxic conditions, and vice versa. The data indicated that HIF- $1 \alpha$ and NF- $\kappa$ B may affect each other and both may reverse EMT and the resistance of pancreatic cancer cells to gemcitabine induced by hypoxia.

As designated, PANC-1 and BxPC-3 cells were treated with gemcitabine (G/10 $\mu \mathrm{mol} / 1$ and $500 \mathrm{nmol} / \mathrm{l}$, respectively), or a combination with HIF- $1 \alpha$ siRNA $(\mathrm{G}+\mathrm{si} \mathrm{HIF-1} \alpha)$ or NF- $\mathrm{NB}(\mathrm{p} 65)$ siRNA (G+siP65) for $48 \mathrm{~h}$ under hypoxic $(\mathrm{H})$ and normoxic (N) conditions, before being stained with Annexin V/PI for flow cytometric determination of the apoptotic rate.

As shown in Fig. 4, the apoptotic rate was increased significantly when cells were treated with gemcitabine under normoxic conditions $(\mathrm{N} / \mathrm{G})$ when compared with the rate in cells treated with gemcitabine under hypoxic conditions $(\mathrm{H} / \mathrm{G})$ 

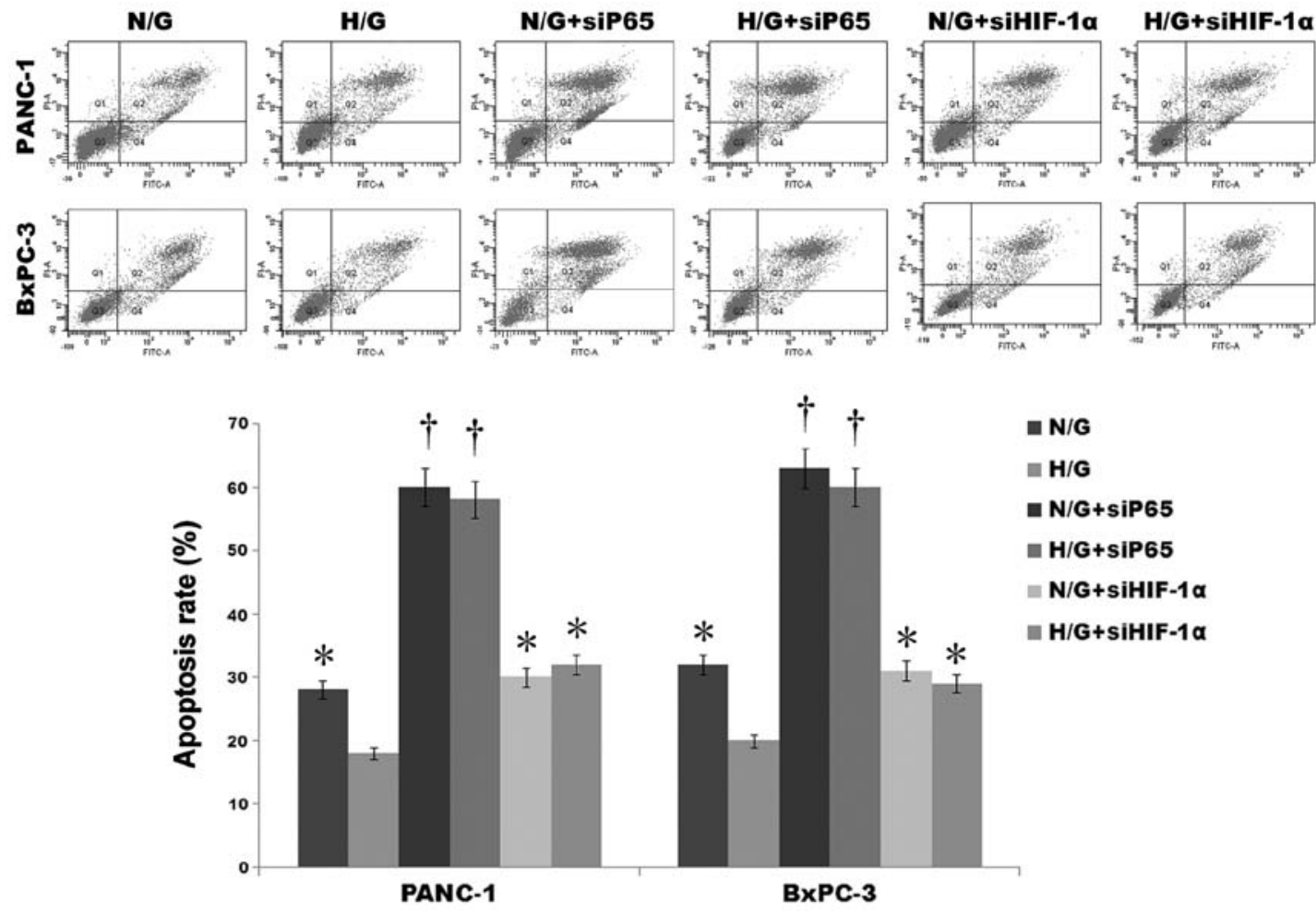

Figure 4. Cell apoptosis. PANC-1 and BxPC-3 cells were treated with gemcitabine (G/10 $\mu \mathrm{mol} / 1$ and $500 \mathrm{nmol} / 1$, respectively), or a combination with HIF-1 $\alpha$ siRNA (G+siHIF-1 $\alpha)$ or NF-kB(p65) siRNA (G+siP65) under hypoxic $(\mathrm{H})$ and normoxic $(\mathrm{N})$ conditions for $48 \mathrm{~h}$. Flow cytometry was performed to measure the apoptosis rates (\%). Bottom panel: apoptosis rates of data presented in the top panel, compared with cells treated with gemcitabine under hypoxic conditions $(\mathrm{H} / \mathrm{G}) .{ }^{*} \mathrm{P}<0.05$ and ${ }^{\dagger} \mathrm{P}<0.01$, significant increase in the apoptosis rate from the control (H/G). HIF-1 $\alpha$, hypoxia-inducible factor-1 $\alpha$; siRNA, small interfering $\mathrm{RNA}$; NF- $\mathrm{kB}$, nuclear factor- $\mathrm{kB}$.

(both $\mathrm{P}<0.05$ ). This result suggests that the apoptosis induced by gemcitabine can be resisted by hypoxia.

Furthermore, our data showed that the apoptosis rate was increased significantly when cells were treated with a combination of gemcitabine and HIF- $1 \alpha$ siRNA under hypoxic conditions $(\mathrm{H} / \mathrm{G}+\mathrm{siHIF}-1 \alpha)$ or NF- $\mathrm{kB}(\mathrm{p} 65)$ siRNA under hypoxic conditions $(\mathrm{H} / \mathrm{G}+\mathrm{siP} 65)$ compared with treatment with gemcitabine alone under hypoxic conditions $(\mathrm{H} / \mathrm{G})$ for $48 \mathrm{~h}(\mathrm{P}<0.05, \mathrm{P}<0.01$, respectively). Meanwhile, our data also showed that the apoptosis rate was not significantly altered when the cells were treated with the combination of gemcitabine and HIF- $1 \alpha$ siRNA $(\mathrm{H} / \mathrm{G}+\operatorname{siHIF}-1 \alpha)$ or NF- $\mathrm{kB}(\mathrm{p} 65)$ siRNA (H/G+siP65) under hypoxic conditions when compared with the apoptosis rate under normoxic conditions (N/G+siHIF-1 $\alpha, \mathrm{N} / \mathrm{G}+\mathrm{siP} 65)$ for $48 \mathrm{~h}$. These findings validate that the involvement of hypoxia in the resistance to apoptosis induced by gemcitabine was mainly attributable to HIF-1 $\alpha$ and NF- $\kappa B$ hyperactivity.

Together, our results suggest that hypoxia-induced EMT and resistance to gemcitabine were mainly attributable to HIF- $1 \alpha$ and NF-kB hyperactivity.

\section{Discussion}

A hypoxic microenvironment is commonly found in the central region of solid tumors. Since hypoxia in tumors is associated with poor prognosis, resistance to chemotherapy and radiation therapy, and increased metastatic potential, targeting hypoxia response pathways is of potential therapeutic value (5). In recent years, it has become increasingly clear that EMT plays important roles in the progression of cancer and is also responsible for the resistant phenotype of cancer cells to conventional chemotherapeutics (10-17). Induction of EMT has been previously demonstrated following hypoxia, as shown by a shift in expression of epithelial markers (E-cadherin) to mesenchymal markers (Vimentin and N-cadherin) (33-36). A number of factors including the zinc finger Snail and several basic helixloop-helix factors such as Twist that transcriptionally repress E-cadherin have emerged as potent EMT drivers during normal development and cancer $(37,38)$. Overexpression of Twist was found to result in an increase in $\mathrm{N}$-cadherin, which leads to a further decrease in E-cadherin expression $(33,39)$. In the present study, we found that when pancreatic cancer cells were exposed to hypoxic conditions for up to $48 \mathrm{~h}$, PANC-1 cells underwent typical EMT morphological and cellular changes. These cells lost cell contact, scattered from cell clusters and acquired a spindle-shaped and fibroblast-like phenotype. In the BxPC 3 cell line, however, morphological and cellular changes did not differ significantly. Thus, BXPC3 cells were more sensitive to chemotherapeutics than PANC-1 cells. The loss of cellular polarity and homotypic adhesion are major components of EMT. One study reported that drug-resistant cells displayed a 'more mesenchymal' phenotype (12). To further confirm whether pancreatic cancer cells undergo EMT when exposed to hypoxia, we determined the expression of markers of epithelial and mesenchymal phenotypes by western blotting. We found that pancreatic cancer cells (PANC-1, BxPC-3) after exposure to hypoxia for $48 \mathrm{~h}$ had 
reduced expression of E-cadherin and increased expression of Vimentin, N-cadherin, Snail and Twist when compared with the levels in cells under a normoxic condition. Furthermore, the pancreatic cancer cells that underwent EMT exhibited a resistant phenotype to conventional chemotherapeutics. Our study also confirmed that hypoxia was responsible for chemoresistance to gemcitabine in pancreatic cancer cells that underwent EMT. In the present study, the process of EMT in pancreatic cancer cells under a hypoxic condition was characterized by $\mathrm{N}$-cadherin, Vimentin, Snail and Twist overexpression and E-cadherin suppression, striking morphological changes to the mesenchymal phenotype and a drug resistance to gemcitabin.

Although different factors are involved in the induction of EMT, studies have previously indicated that HIF-1 $\alpha$ (33) and NF- $\kappa$ B (26-29) have a critical role in EMT. It was previously reported that HIF-1 $\alpha$ may regulate $\mathrm{NF}-\kappa \mathrm{B}$ expression $(21,22,40,41)$. Other studies reported that $\mathrm{NF}-\kappa \mathrm{B}$ transcriptionally induces HIF-1 $\alpha$ expression $(24,25)$. Therefore, the correlation between NF- $\kappa \mathrm{B}$ and HIF-1 is not fully defined. In our experiments, EMSA performed with the $\mathrm{NF}-\kappa \mathrm{B}$ probe in pancreatic cancer cells demonstrated that the DNA binding activity of $\mathrm{NF}-\kappa \mathrm{B}$ was increased as well as the expression of NF- $\kappa \mathrm{B}(\mathrm{p} 65)$ and $\mathrm{HIF}-1 \alpha$ protein in hypoxic cells in a time-dependent manner. Our data also demonstrated that the overexpression of NF- $\kappa \mathrm{B}(\mathrm{p} 65)$ protein and NF- $\kappa \mathrm{B}$ DNA binding activity were inhibited by HIF-1 $\alpha$ siRNA, and vice versa. Expression of HIF-1 $\alpha$ protein was also inhibited by $\mathrm{NF}-\kappa \mathrm{B}(\mathrm{p} 65)$ siRNA. It is well known that EMT characteristics must be reversed to overcome drug resistance, which may lead to the sensitization of drug-resistant cancer cells to conventional chemotherapeutic agents. The results presented in the present study showed that HIF- $1 \alpha$ siRNA and NF- $\kappa \mathrm{B}(\mathrm{p} 65)$ siRNA, respectively, may reverse EMT and increase the sensitivity of pancreatic cancer cells to gemcitabine. The complete results of the present study indicated that the EMT program attributable to hypoxia was driven by a biochemical loop, NF- $\mathrm{BB}$ and HIF-1, and these two principal transcription factors can regulate each other in this process.

In conclusion, these exciting results should provide incentives for further investigation and optimization in establishing the mechanistic role of the HIF- $1 \alpha$ and NF- $\kappa$ B loop in the reversal of EMT characteristics and drug resistance and their utility in the clinical setting for the treatment of pancreatic cancer for which there is no effective and curative therapy.

\section{Acknowledgements}

This work was supported in part by grants from the Natural Science Foundation of Heilongjiang Province, China (H201373 to Z.-X.C.), Jiamusi University Youth Foundation (q2013-024 to Z.-X.C.). China Postdoctoral Science Foundation, China (2012M520769 to D.-W.W.) and Hei Long Jiang Postdoctoral Foundation, China (LBH-Z12201 to D.-W.W.). The funders had no role in study design, data collection and analysis, decision to publish, or preparation of the manuscript.

\section{References}

1. Beger HG, Rau B, Gansauge F, Poch B and Link KH: Treatment of pancreatic cancer: challenge of the facts. World J Surg 27: 1075-1084, 2003.
2. Kullmann F, Hollerbach S, Dollinger MM, Harder J, Fuchs M, Messmann H, Trojan J, Gäbele E, Hinke A, Hollerbach C and Endlicher E: Cetuximab plus gemcitabine/oxaliplatin (GEMOXCET) in first-line metastatic pancreatic cancer: a multicentre phase II study. Br J Cancer 100: 1032-1036, 2009.

3. Herrmann R, Bodoky G, Ruhstaller T, Glimelius B, Bajetta E, Schüller J, Saletti P, Bauer J, Figer A, Pestalozzi B, Köhne CH, Mingrone W, Stemmer SM, Tàmas K, Kornek GV, Koeberle D, Cina S, Bernhard J, Dietrich D, Scheithauer W; Swiss Group for Clinical Cancer Research; Central European Cooperative Oncology Group: Gemcitabine plus capecitabine compared with gemcitabine alone in advanced pancreatic cancer: a randomized, multicenter, phase III trial of the Swiss Group for Clinical Cancer Research and the Central European Cooperative Oncology Group. J Clin Oncol 25: 2212-2217, 2007.

4. Bergman AM, Pinedo HM and Peters GJ: Determinants of resistance to 2',2'-difluorodeoxycytidine (gemcitabine). Drug Resist Updat 5: 19-33, 2002.

5. Harris AL: Hypoxia - a key regulatory factor in tumour growth. Nat Rev Cancer 2: 38-47, 2002.

6. Maxwell PH: The HIF pathway in cancer. Semin Cell Dev Biol 16: 523-530, 2005.

7. Semenza GL: Targeting HIF-1 for cancer therapy. Nat Rev Cancer 3: 721-732, 2003.

8. Huber MA, Kraut N and Beug H: Molecular requirements for epithelial-mesenchymal transition during tumor progression. Curr Opin Cell Biol 17: 548-558, 2005.

9. Cannito $S$, Novo E, Compagnone A, Valfrè di Bonzo L, Busletta $C$ Zamara E, Paternostro C, Povero D, Bandino A, Bozzo F, Cravanzola C, Bravoco V, Colombatto S and Parola M: Redox mechanisms switch on hypoxia-dependent epithelial-mesenchymal transition in cancer cells. Carcinogenesis 29: 2267-2278, 2008.

10. Shah AN, Summy JM, Zhang J, Park SI, Parikh NU and Gallick GE: Development and characterization of gemcitabineresistant pancreatic tumor cells. Ann Surg Oncol 14: 3629-3637, 2007.

11. Wang Z, Li Y, Kong D, Banerjee S, Ahmad A, Azmi AS, Ali S, Abbruzzese JL, Gallick GE and Sarkar FH: Acquisition of epithelial-mesenchymal transition phenotype of gemcitabineresistant pancreatic cancer cells is linked with activation of the Notch signaling pathway. Cancer Res 69: 2400-2407, 2009.

12. Arumugam T, Ramachandran V, Fournier KF, Wang $\mathrm{H}$, Marquis L, Abbruzzese JL, Gallick GE, Logsdon CD, McConkey DJ and Choi W: Epithelial to mesenchymal transition contributes to drug resistance in pancreatic cancer. Cancer Res 69: 5820-5828, 2009.

13. Hiscox S, Jiang WG, Obermeier K, Taylor K, Morgan L, Burmi R, Barrow D and Nicholson RI: Tamoxifen resistance in MCF7 cells promotes EMT-like behaviour and involves modulation of $\beta$-catenin phosphorylation. Int J Cancer 118: 290-301, 2006.

14. Kajiyama H, Shibata K, Terauchi M, Yamashita M, Ino K, Nawa A and Kikkawa F: Chemoresistance to paclitaxel induces epithelial-mesenchymal transition and enhances metastatic potential for epithelial ovarian carcinoma cells. Int J Oncol 31: 277-283, 2007.

15. Yang AD, Fan F, Camp ER, van Buren G, Liu W, Somcio R, Gray MJ, Cheng H, Hoff PM and Ellis LM: Chronic oxaliplatin resistance induces epithelial-to-mesenchymal transition in colorectal cancer cell lines. Clin Cancer Res 12: 4147-4153, 2006.

16. Fuchs BC, Fujii T, Dorfman JD, Goodwin JM, Zhu AX, Lanuti M and Tanabe KK: Epithelial-to-mesenchymal transition and integrin-linked kinase mediate sensitivity to epidermal growth factor receptor inhibition in human hepatoma cells. Cancer Res 68: 2391-2399, 2008.

17. Yauch RL, Januario T, Eberhard DA, Cavet G, Zhu W, Fu L, Pham TQ, Soriano R, Stinson J, Seshagiri S, Modrusan Z, Lin CY, O'Neill V and Amler LC: Epithelial versus mesenchymal phenotype determines in vitro sensitivity and predicts clinical activity of erlotinib in lung cancer patients. Clin Cancer Res 11: 8686-8698, 2005.

18. Wang W, Abbruzzese JL, Evans DB, Larry L, Cleary KR and Chiao PJ: The nuclear factor- $\kappa \mathrm{B}$ RelA transcription factor is constitutively activated in human pancreatic adenocarcinoma cells. Clin Cancer Res 5: 119-127, 1999.

19. Liptay S, Weber CK, Ludwig L, Wagner M, Adler G and Schmid RM: Mitogenic and antiapoptotic role of constitutive $\mathrm{NF}-\kappa \mathrm{B} /$ relactivity in pancreatic cancer. Int J Cancer 105: 735-746, 2003. 
20. Chandler NM, Canete JJ and Callery MP: Increased expression of NF- $\mathrm{KB}$ subunits in human pancreatic cancer cells. J Surg Res 118: 9-14, 2004.

21. Chandel NS, Trzyna WC, McClintock DS and Schumacker PT: Role of oxidants in NF- $\kappa \mathrm{B}$ activation and TNF- $\alpha$ gene transcription induced by hypoxia and endotoxin. J Immunol 165: 1013-1021, 2000.

22. Lluis JM, Buricchi F, Chiarugi P, Morales A and FernandezCheca JC: Dual role of mitochondrial reactive oxygen species in hypoxia signaling: activation of nuclear factor- $\kappa \mathrm{B}$ via c-SRC and oxidant-dependent cell death. Cancer Res 67: 7368-7377, 2007.

23. Yokoi $\mathrm{K}$ and Fidler IJ: Hypoxia increases resistance of human pancreatic cancer cells to apoptosis induced by gemcitabine. Clin Cancer Res 10: 2299-2306, 2004.

24. Rius J, Guma M, Schachtrup C, Akassoglou K, Zinkernagel AS, Nizet V, Johnson RS, Haddad GG and Karin M: NF- $\kappa$ B links innate immunity to the hypoxic response through transcriptional regulation of HIF-1 $\alpha$. Nature 453: 807-811, 2008.

25. Belaiba RS, Bonello S, Zähringer C, Schmidt S, Hess J, Kietzmann $\mathrm{T}$ and Görlach A: Hypoxia up-regulates hypoxia-inducible factor-1 $\alpha$ transcription by involving phosphatidylinositol 3-kinase and nuclear factor $\mathrm{\kappa B}$ in pulmonary artery smooth muscle cells. Mol Biol Cell 18: 4691-4697, 2007.

26. Huber MA, Azoitei N, Baumann B, Grünert S, Sommer A Pehamberger H, Kraut N, Beug H and Wirth T: NF- $\kappa$ B is essential for epithelial-mesenchymal transition and metastasis in a model of breast cancer progression. J Clin Invest 114: 569-581, 2004

27. Shin SR, Sánchez-Velar N, Sherr DH and Sonenshein GE: 7,12-Dimethylbenz (a) anthracene treatment of a c-rel mouse mammary tumor cell line induces epithelial to mesenchymal transition via activation of nuclear factor- $\kappa \mathrm{B}$. Cancer Res 66: 2570-2575, 2006.

28. Chua HL, Bhat-Nakshatri P, Clare SE, Morimiya A, Badve S and Nakshatri $\mathrm{H}$ : NF- $\mathrm{B}$ B represses E-cadherin expression and enhances epithelial to mesenchymal transition of mammary epithelial cells: potential involvement of ZEB-1 and ZEB-2. Oncogene 26: 711-724, 2007.

29. Julien S, Puig I, Caretti E, Bonaventure J, Nelles L, van Roy F, Dargemont C, de Herreros AG, Bellacosa A and Larue L: Activation of NF- $\kappa$ B by Akt upregulates Snail expression and induces epithelium mesenchyme transition. Oncogene 26: 7445-7456, 2007

30. Wang SJ, Gao Y, Chen H, Kong R, Jiang HC, Pan SH, Xue DB, Bai XW and Sun B: Dihydroartemisinin inactivates NF- $\kappa$ B and potentiates the anti-tumor effect of gemcitabine on pancreatic cancer both in vitro and in vivo. Cancer Lett 293: 99-108, 2010.
31. Kong R, Sun B, Jiang H, Pan S, Chen H, Wang S, Krissansen GW and Sun X: Downregulation of nuclear factor-kappaB p65 subunit by small interfering RNA synergizes with gemcitabine to inhibit the growth of pancreatic cancer. Cancer Lett 291: 90-98, 2010.

32. Franovic A, Gunaratnam L, Smith K, Robert I, Patten D and Lee S: Translational up-regulation of the EGFR by tumor hypoxia provides a non mutational explanation for its overexpression in human cancer. Proc Natl Acad Sci USA 104: 13092-13097, 2007.

33. Yang MH, Wu MZ, Chiou SH, Chen PM, Chang SY, Liu CJ, Teng SC and Wu KJ: Direct regulation of TWIST by HIF-1 $\alpha$ promotes metastasis. Nat Cell Biol 10: 295-305, 2008

34. Hotz B, Arndt M, Dullat S, Bhargava S, Buhr HJ and Hotz HG: Epithelial to mesenchymal transition: expression of the regulators snail, slug, and twist in pancreatic cancer. Clin Cancer Res 13: 4769-4776, 2007.

35. Wang B, Zhang Z and Ke Y: Conversion of cadherin isoforms in cultured human gastric carcinoma cells. World J Gastroenterol 12: 966-970, 2006.

36. Thiery JP and Sleeman JP: Complex networks orchestrate epithelial-mesenchymal transitions. Nature Rev Mol Cell Biol 7: 131-142, 2006.

37. Nieto MA: The snail superfamily of zinc-finger transcription factors. Nat Rev Mol Cell Biol 3: 155-166, 2002.

38. Peinado H, Olmeda D and Cano A: Snail, Zeb and bHLH factors in tumour progression: an alliance against the epithelial phenotype? Nat Rev Cancer 7: 415-428, 2007.

39. Alexander NR, Tran NL, Rekapally H, Summers CE, Glackin C and Heimark RL: N-cadherin gene expression in prostate carcinoma is modulated by integrin-dependent nuclear translocation of Twist1. Cancer Res 66: 3365-3369, 2006.

40. Walmsley SR, Print C, Farahi N, Peyssonnaux C, Johnson RS, Cramer T, Sobolewski A, Condliffe AM, Cowburn AS, Johnson $\mathrm{N}$ and Chilvers ER: Hypoxia-induced neutrophil survival is mediated by HIF-1 $\alpha$-dependent NF- $\kappa \mathrm{B}$ activity. J Exp Med 201: 105-115, 2005.

41. Carbia-Nagashima A, Gerez J, Perez-Castro C, Paez-Pereda M, Silberstein S, Stalla GK, Holsboer F and Arzt E: RSUME, a small RWD-containing protein, enhances SUMO conjugation and stabilizes HIF-1 $\alpha$ during hypoxia. Cell 131: 309-323, 2007. 